\title{
DISCHARGE OF DUTIES BY EMPLOYERS VIS-A-VIS ASSURANCE ON PROTECTION OF WOMEN FROM WORK PLACE SEXUAL HARASSMENT
}

\section{MUKULIKA DINDA}

Assistant Professor in Law, Law College Durgapur, G.T.Road, Burdwan, West Bengal, India

\begin{abstract}
Sexual harassment at workplace is the new forms of violence against women in Mao India. Radical feminism views that patriarchy, private sphere, economic dependence, sexuality and women's biological features are the main causes for the oppression of women. Now, the status of women is changing day by day, giving rise to an evolution, where they claim their substantive rights such as participation in every sphere of life, bridging the gap between their struggle and rights, thereby gaining economic independence as a consequence of the series of struggle. The new alteration form of masculinity power is sexual harassment, which is spread around the globe, and is called "unwanted intimacy", "sexual molestation" and "sexual solicitation etc. This paper studies only the discharge of duties of the employers and these duties are provided in SHW Act, 2013.

KEYWORDS: Mao India, Sexual harassment, Substantive rights \&Workplace
\end{abstract}

Received: May 12, 2020; Accepted: Jun 02, 2020; Published: Jun 12, 2020; Paper Id.: IJHRMRAUG20202

\section{INTRODUCTION}

'One is not born, but rather becomes, a woman'

\section{- Simon de Beauvoir}

Violence against women is static in women's life from womb to tomb. Indian Mythological belief places women as a Goddess -Lakshmi as of wealth, Saraswati as in Learning, Parvati as of Power. Though women are holding inferior status that is blossoming in Hindu Mythological story, Mahishasura Mardini in which Mahishasura, buffalo demon was attacked by Goddess Durga that time,he said with a sarcastic laugh and inferior eyes to the Goddess as a woman that a woman would defeat the supreme holder of masculinity power, which was gifted from Lord Brahma. That means, War Fare is not for a woman, and the woman cannot participate in the public sphere. In Treta Yuga Sita in Ramayana and Draupadi in Mahabharata, are the victims of violence against women and their right to life, dignity and freedom had been taken away from them treated as a stigmatised unchaste woman, and a wage in gambling match between Kauravas and Pandavas. Islam ordains "underneath mother's feet is the paradise......"The one of the tenets of Buddhism proclaims "One is reborn a woman because of one's bad karma". Women's rights are dominated within the periphery of cultural practice and religious values which are child marriage, widowhood and Sati, purdah system and female illiteracy that is the view of Katherine Mayo's during the advent of British Raj System. After that, new crimes steps down in our society and also movement was started suchas theCampaign Against Dowry in 1980, Agitation against Rape in 1979, the issue of personal law in 1985, the Agitation against Sati in 1987-88.Remaining some unending issues, other new forms of violence against women is added in the name of Sexual Harassment at the workplace, because women are equally footstep with men in every part of life. 


\section{FEMINISM AND SEXUAL HARASSMANT AT WORK PLACE}

Feminist scholar, Catharine A Mackinnon argues that women are sexually harassed, because of their sex. She argues that there is inequality of power, for which systematic subordination of women has existed. She argues that men do not perceive women as workers, but as sexual beings in the workplace. ${ }^{1}$ A Vindication of the Rights of Women by Marry Wollstonecraft in 1792, in this Book woman is foremost human beings and not sexual beings ${ }^{2}$.According to Kate Millett, institutionalised patriarchy in all spheres of life produces women's oppression. Socialist feminism analyses the power of man over men of its class origin and patriarchal roots. ${ }^{3}$ Feminist argues that the sexuality of women is imposed by society conditionally, not by nature andsexuality is gendered sexuality, which is evolved from a culture. According to Michel Foucault, Sexuality is not a product of a pre-event essence. Knowledge of sexuality is structures through the use of language. Broude defined sexuality as a person's capacity for sexual feelings. ${ }^{4}$ Sexuality is one of the factors to arise in sexual harassment in India.

\section{MEANING OF SEXUAL HARASSMENT AND DIFFERENT CONNOTATION}

This offence is a sexual hazard, which is sensitised in the Case of Vishaka V. State of Rajasthan, ${ }^{5}$ that includes such unwelcome sexually determined behaviour (whether directly or by implication) as :

- "Physical contact and advances

- A demand or request for sexual favours;

- Sexually coloured remarks;

- $\quad$ Showing pornography;

- Any other unwelcome physical, verbal or non-verbal conduct of sexual nature."

After a long break, The Sexual Harassment of Women at Workplace (Prevention, Prohibition and Redressal) Act, 2013 clearly defines the word of Sexual Harassment at Work Place as shown Vishaka's Case, August 1997. The Criminal Law (Amendment) Act, 2013 defines in Section 354A (1) as a man committing any act-

- "Physical contact and advances involving unwelcome and explicit sexual overtures; or

- A demand or request for sexual favours; or

- Showing pornography against the will of a woman; or

- Making sexually coloured remarks,

Shall be guilty of the offence of sexual harassment."

The researcher focuses on the important variables such as "Women", "Workplace"," Employee" and "Employer". Where a "Woman" means,aggrieved woman in section 2(a) of the above mentioned Act and includes students in

\footnotetext{
${ }^{1}$ Mackinnon, A .C (1979). Sexual Harassment of Working Women: A Case Of Sex Discrimination.(19 ${ }^{\text {th }}$.ed), New Haven, USA: Yale University Press

${ }^{2}$ Rao M ( 2008). Law relating Women \& Children. (2 ${ }^{\text {nd }}$.ed), Lalbagh, Lucknow :EBC Publishing (p) LTD

${ }^{3}$ Chatterjee A. S (2010).Women in perspective : Essay on Gender issues.( $1^{\text {st }}$.e d), Daryaganj, New Delhi :Vitasta Publication House

${ }^{4}$ Mete ,Dr. J.,\& Biswas , P. (2018) . Gender School and Society . ( $\left.2^{\text {nd }}\right)$ Kolkata :Rita Book Agency

${ }^{5}$ AIR 1997 SC3011 (1997)
} 
Collegesand Universities.' Workplace 'means workplace in section 2(0) of above Act and includes Colleges and Universities. "Employee"means in section 2(f) of the above Act and includes research scholar also. "Employer" means in section 2(g) of the above Act and covers Principal, Head of the Department in colleges and Vice -Chancellor of University.

\section{THE OBJECT OF THE STUDY}

The Sexual Harassment of women at Workplace (Prevention, Prohibition and Redressal) Act 2013 (W.E.F.09.12.2013) has cast certain duties on the employer to protect the Right of the women to a safe environment, free from sexual harassment at workplace. This research study is undertaken to study the real scenario about the fulfilment of those duties by the employer, in an educational institution under the district of Burdwan in West Bengal.

\section{METHODOLOGY FOR DATA COLLECTION}

The researcher used Questionnairetechnique throughRTI and respondent number is 83, which are two Universities and colleges in the District of Burdwan.

\section{Reasons for the rapid growth and spread as the menace of sexual harassment at the workplace in India}

\section{Inequality of power between Gender and Sex}

Gender and Sex are the social variables, which are then identified by the feminist scholar and these variables have existed in our society. Sex means male and female. It is seen that biologically male are stronger than women. Gender is created by cultural construct. Gender limits the role of women as passive, receptiveness and caring, and men are naturally as aggressiveness, assertiveness and braveness. Gender is not only symbolizes difference, but also symbolizes discrimination.

\section{Workplace Bullying}

"Work place Bullying" is defined as the "intentional infliction of a hostile work environment upon an employee by a coworker or co-workers, typically through a combination of verbal and nonverbal behaviours." ${ }^{6}$ Job portal Career Builder.in investigatethat about 55 per cent of Indian Workers have been bullied at work. In this study, two common forms of bullying are found that 33 per cent employees are bullied at work, but accused demand that they are falsely accused of mistakes not commit such work \& 33 per cent employees do not cognize or acknowledge their comments, but they face such situation. ${ }^{7}$

\section{Capitalism Activity by the Employer}

Marxist Feminists places the women as a distinct economic class and obligates the subordination of women by enforcing their economic dependence on men. The Employer looks that matter which is profit making their world not as protective and assurance of security given to an employee for any sexual anomaly in their workplace.

\section{Pro- family Nature of Women}

Women are always committed to their family. When they are sole bread earner for their family, they even sacrifice their dignity for saving their family and own, that is reflected "THE BODY AS A WEAPON EMBODIMENT, WORK AND

\footnotetext{
${ }^{6}$ Fogg P. (2008). Academic Bullies. The Chronicle of Higher Education , 55 (3), B10 . Available at https://www.chronical.com>article Ac...

${ }^{7}$ Balakrishnan, R(2017), 'It is not always about sexual harassment,bullying at the workplace can be harmful too, Your story ' available at http://yourstory.com/
} 


\section{IDENTITY" ${ }^{\prime 8}$}

\section{Women occupying, Gainingsame status as men and entering all Economic Arenas}

The Five Year Strategic Plan of the Ministry of Women and Child Development for 2011-16 states that the workforce participation rate of women in rural area is $31 \%$, whereas it is $55 \%$ for men. Women's share of the organised sector and public sector is less than $20 \%$. Their share in Central Government employment is less than $8 \%{ }^{9}$

\section{Domestic Remedies for the Protection of Women from the Sexual Harassment at Workplace:}

1. Articles 14, 15, 16,19(g), 21,39(d), 42, 51-A, 253 with Articles 32 and 226 of the Constitution of India - These constitutional mandate use as a weapon for the protection of sexually harassed women at workplace, and helps the victims to live with dignity.

2. Sections 294, 354, 354A, 354B, 354D, 376A, 376B, 376C, 376D of Indian Penal Code, 1860 \& Criminal Law Amendment Act 2013 and 114A in the Evidence Act, 1872 -With the help of these sections, any women canseek justice and Under gravity of the offences, the punishment is provided to the offender from life imprisonment to death for the deterrence, retribution, prevention, reformation and expiation of the offender.

3. The Information Technology (Amendment) Act, 2008 and Indecent Representation of Women (Prohibition) Act, 1986 The two important legislations protect the women from sexual harassment at workplace.

4. The National Commission for Women Act, 1990 and The Protection of Human Rights Act, 1993-The main object of two Acts is for the better protection of women's right with campaigning and better protection of the women's human rights.

5. The Sexual Harassment of Women (Prevention, Prohibition and Redressal) Act, 2013- On April 23,2013 by way of notification in the Official Gazette of India every working women are free to exercise their economic rights to participate in every public sphere, and they can protect their bodily integrity rights by freeing themselves from sexual harassment at workplace.

\section{Important International Endeavour Addressing the Issue of Sexual Harassment At Workplace:}

1. The United Nations Convention on the Elimination of All Forms of Discrimination Against Women(1979)- Under this Convention Article 11 states, "States Parties shall take all appropriate measures to eliminate discrimination against women in the field of employment in order to ensure, on a basis of equality of men and women, the same rights,in particular:

- The right to work as an inalienable right of human beings;

- The right to the same employment opportunities, etc.

- The right to protection of health and safety in working conditions, etc."

\footnotetext{
${ }^{8}$ Thapan, M (2009). Living The Body Embodiment, Womanhood and Identity in Contemporary India. ,( $1^{\text {st }}$.ed ).New Delhi, India: Sage Publication

${ }^{9}$ Mahapatra, H (2015). Statusof Women in Indian Society. Journal of Research in Humanities and Social Science, 3(6)3336
} 
2.The Nairobi Forward Looking Strategies for the Advancement of Women- It directly referred the issue of sexual harassment as such enhancement of job security and rights of young women to be free from sexual violence, sexual harassment and sexual exploitation etc.,

3. The Vienna Declaration and Programme of Action in 1993- It recognizes "sexual harassment which is incompatible with human dignity."

4. Declaration on the Elimination of Violence against Women- This document mentioned that women are the subject of sexual violence, and women can access to the mechanism of justice through the national legislations .

5. Beijing Declaration and Platform for Action in 1995- The Action highlights that sexual harassment is the obstacle for women's development and peace.

6. The Violence and Harassment Convention (C190) and Recommendation in 2019 -The Convention points out that "violence and harassment" causes physical harm, psychological harm, sexual harm and economic harm to the concerned person. All types' workers such as contractual worker, trainees, interns and volunteers etc. are protected fromviolence in all sectors.

\section{A Glance at Sexual Harassment in Educational Institutions:}

The All India Survey on Higher Education 2014-2015, Ministry of Human Resource Development, Department of Higher Education, New Delhi reports that female students constituted 53\% of the Bachelor of Arts (BA) programme across the country; $47.6 \%$ of the Bachelor of Science; $45.5 \%$ of the Bachelor of Commerce programme; $52 \%$ of the BA Honours; $64 \%$ of the Bachelor of Education (B.ED), 58.2\% of the Master of Arts (M.A) and 57.9\% of the Master of Sciences (M. Sc). But in recent years, there are alarming low female Work Participation Rates in India and employment crisis of Indian Women. $^{10}$

NHRC Case No.1081/25/5/2014-WC/OC dated 05.09.14 and NHRC Case No.111/25/5/2014-WC/OC dated 11.09.14- Complainant is one Non-Governmental Organization called MANAB regarding the allegation of Sexual Harassment of an unemployed lady By Registrar, Bose Institute, Kolkata. During the enquiry the name and particulars could not be established.The petitioner was commenced through email for obtaining details of the victim lady and even he was requested to meet the enquiring officer at Kolkata Police Headquarters, Lalbazar, and Kolkata for furnishing details of the incident for the sake of enquiry. The authority of the TV as "24 Ghanta" was approached for obtaining the video footage.However, none has the respondent yet. The victim lady did not approached Kolkata police in this regard.

Case No.-1318/25/5/2014-WC- Complainant, MANAB, Non Governmental Organization alleged that a girl student of Jadavpur University was subjected to sexual assault inside the campus by some unlawful miscreants. When the students protested,they were beaten severely at the instance of the state and non-state agencies as a result 36 students were hospitalised and 40 students were arrested. Even though the matter was brought to the notice of the Vice Chancellor, he also tried to suppress the incident. Thus the complainant has sought the intervention of the commission.

New Delhi dated on 20/3/2018 - Police had arrested Atul Johri, Professor in Jawaharlal Nehru University for sexually harassing several women students. Then professor was granted bail by Ritu Singh, a Magistrate with a bail bond

\footnotetext{
${ }^{10}$ Mazumdar, I., \& Neetha, N. (2011).Gender dimension employment trends in India. Economic \& Political Review .46(43) $118-126$
} 
of Rs. 30,000 for each of the eight FIRs registered against him. Women's rights organisation including All India Democratic Women's Association and All India Mahila Sanskritik Sanghatan demonstrated outside the police station, demanding Johri's arrest. ${ }^{11}$

New Delhi dated on 16/9/ 2018 - Metropolitan Magistrate, Charu Gupta ordered framing of charges against R.K Pachauri,TERI boss under section 354, 354A and 509 of Indian Penal Code,1862. A research analyst complained to cops in Feb 2015 that Pachauri repeatedly sent emails, texts and What Sapp messages soon after she joined TERI. In the charge sheet, spilling to over 1,400 pages, that Delhi police filed in March 2016, they had claimed there was "sufficient evidence" against Pachauri that he had sexually harassed, stalked and threatened the complainant.$^{12}$

\section{Discharge Vis- A- Vis Assurance from the Employer for the protection of Women from the Sexual Harassment at workplace}

Sexual harassment is the nerve-racking and mortifying form of violence and various countries of the world take legislative measures for saving the social and economic life of women. English Court awarded psychiatric damages arising out of occupational stress and negligence ofthe employer. In the case of Walker v. Northumberland County Council ${ }^{13}$, US Federal Law prescribes vicarious liability of the employer in case of failure to take immediate and appropriate action regarding the issue of sexual harassment at workplace. The Supreme Court held that the "state" has the vicarious liability to pay compensation for the rape of a lady, Bangladeshi national and this sexual violence was committed by theemployees of Indian Railways. ${ }^{14}$ The victims of sexual harassment at workplace can seek justice under Tort Law. ${ }^{15}$ In the Case of Medha Kotwal Lele v. Union of India ${ }^{16}$, the Supreme Court highlights the effects of non-compliance and non-adherence to the Vishakha guidelines in the workplace in India, and has shown the necessity to enact particular legislation. The Sexual Harassment of Women at Workplace (Prevention, Prohibition and Redressal) Act,2013 mandates the establishment of Internal Complaint Committee by the employer, establishment of Local Complaint Committee by the District Officer, Duties of Employer and Duties and Powers of District Officer under Sections 4, 5, 6, 19 and 20 of above mentioned Act.

\section{EMPIRICAL STUDY REPORT AND ANALYSIS}

Following are the tables, which are shown the result of duties ofthe employer in educational institutions.

The Data No. 1: Knowledge about the Sexual Harassment of Women at Workplace (Prevention, Prohibition and Redressal)Act, 2013 and Knowledge about the Duties of Employer provided in this Act.

\begin{tabular}{|c|c|c|}
\hline SHWAct & No.Respondents & Percentage \\
\hline Yes & 5 & 6.02 \\
\hline No & 78 & 93.97 \\
\hline Total & $\mathbf{8 3}$ & $\mathbf{1 0 0}$ \\
\hline
\end{tabular}

The table has shown that majority of respondents have no knowledge about SHW Act.

\footnotetext{
${ }^{11}$ Press Trust of India,"JNUprof held for sexual harassment “ Times of India, March 202018

${ }^{12}$ Times News Network,"Pachauri to face molestation trial" Times of India, September 162018

${ }^{13}$ Walkerv. Northumberland County Council,(1995) 1 ALL ER737

${ }^{14}$ Railway Board v Chandrima Das(2000) 2 S.C.C.988(India)

${ }^{15}$ Jay Laxmi Salt Works (p) Ltd v. State of Gujrat,(1994) 3 S.C.C492(India)

${ }^{16}$ WP(Crl.) No 173-177 of 1999(India)
} 
The DataNo. 2: Duty to constitute the Internal Complaint Committee under SHW Act of Employers.

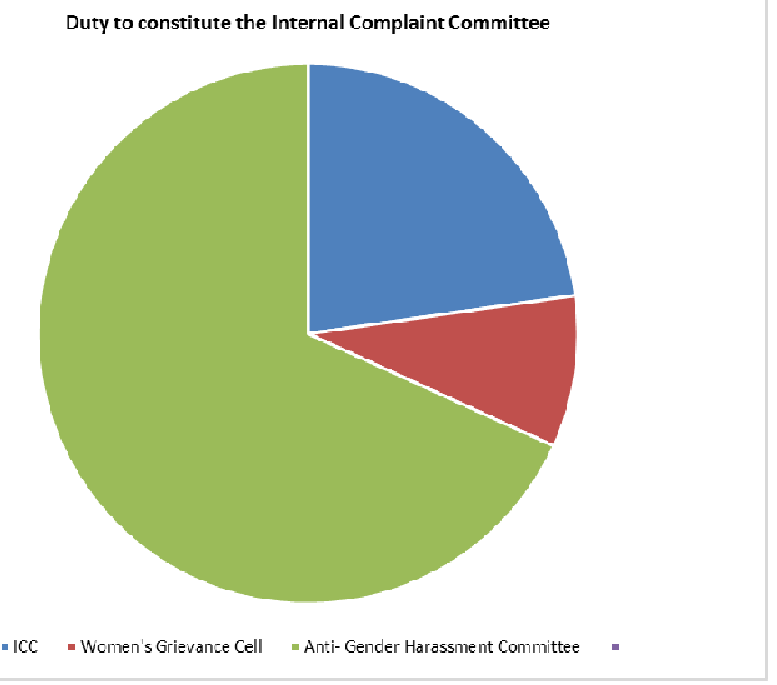

The above pie chart is drawn that $23 \%$ of respondents is established ICC committee out of eighty three respondents. Anti-Gender Harassment Committee is established by $68 \%$ respondents with little much concern about sexual harassment Problems. Women's Grievance Cellis established by 9\%respondents out of eighty three respondents.

The Data No. 3: Duties of Employer toappoint the Senior Level Officer as Presiding Officer.

\begin{tabular}{|c|c|c|}
\hline $\begin{array}{c}\text { The Appointment of Presiding } \\
\text { Officer of the ICC from the Senior } \\
\text { Level Officer }\end{array}$ & $\begin{array}{c}\text { No. } \\
\text { Respondents }\end{array}$ & Percentage \\
\hline Yes & 5 & 6.02 \\
\hline No & 61 & 73.49 \\
\hline N.A & 17 & 20.48 \\
\hline Total & $\mathbf{8 3}$ & $\mathbf{1 0 0}$ \\
\hline
\end{tabular}

The above table has shown poor responsibility to appoint presiding officer.

The Data No 4: Appointment of One member from amongst Non-Governmental Organisation or a person familiar with the Issue of Sexual Harassment by the Employers and payment of Fees and Allowances Payment by the Employers to those Members.

\begin{tabular}{|c|c|c|}
\hline $\begin{array}{c}\text { Member from NGO \& a person Familiar with } \\
\text { the issue of sexual harassment and Fees and } \\
\text { Allowances payment to these members }\end{array}$ & No. Respondents & Percentage \\
\hline Yes & 5 & 6.02 \\
\hline No & $\mathbf{7 8}$ & $\mathbf{9 3 . 9 7}$ \\
\hline Total & $\mathbf{8 3}$ & $\mathbf{1 0 0}$ \\
\hline
\end{tabular}

The above table also has shown poor responsibility of employersregarding the fees and allowances payment to the members.

The Data No. 5: Display of Notice of ICC by the Employer at the conspicuous part in workplace and withdetailing Inflicted Punishment for Sexually Harassed women inside the Workplace.

\begin{tabular}{|c|c|c|}
\hline $\begin{array}{c}\text { Notice for composition of ICC and Punishment for } \\
\text { Sexually Harassed a women }\end{array}$ & No. Respondents & Percentage \\
\hline Yes & 3 & 3.61 \\
\hline No & 78 & 93.97 \\
\hline Under Process & 2 & 2.40 \\
\hline
\end{tabular}


The above table shows that only three respondents have displayed notice inthe Public domain. Fourteen respondents did not display any notice. Two respondents are in under process.

The Data No.6:Measures of a Safe Working Environment to women at workplace and protection from outsiders

\begin{tabular}{|c|c|c|}
\hline $\begin{array}{c}\text { Measures of aSafe Environment for } \\
\text { women and others measures to ensure } \\
\text { safety from the outsiders coming to the } \\
\text { workplace }\end{array}$ & No. Respondents & Total \\
\hline Yes & 83 & 100 \\
\hline No & 0 & 0 \\
\hline Total & $\mathbf{8 3}$ & $\mathbf{1 0 0}$ \\
\hline
\end{tabular}

This table reveals that eighty three respondents have taken measures for the safe environment at the workplace.

The Data No.7: Workshop or Awareness programme by Employers to Sensitise Employees with the provision of SHW Act, 2013

\begin{tabular}{|c|c|c|}
\hline $\begin{array}{c}\text { Workshop or } \\
\text { Awareness } \\
\text { Programme }\end{array}$ & $\begin{array}{c}\text { No. } \\
\text { Respondents }\end{array}$ & Percentage \\
\hline Yes & 2 & 2.40 \\
\hline Under Process & 3 & 3.61 \\
\hline No & 78 & 93.97 \\
\hline Total & $\mathbf{8 3}$ & $\mathbf{1 0 0}$ \\
\hline
\end{tabular}

The above table shows that only two respondents organised workshop or awareness programme.

The Data Number 8: An Orientation programme for the members of the ICC by the Employers.

\begin{tabular}{|c|c|c|}
\hline $\begin{array}{c}\text { Orientation } \\
\text { Programme }\end{array}$ & $\begin{array}{c}\text { No. } \\
\text { Respondents }\end{array}$ & Percentage \\
\hline Yes & 2 & 2.40 \\
\hline Under Process & 3 & 3.61 \\
\hline No & 78 & 93.97 \\
\hline Total & $\mathbf{8 3}$ & $\mathbf{1 0 0}$ \\
\hline
\end{tabular}

The above table shows that one respondent organised orientation programme for the members of ICC ON 24th March 2015, and resource person name is Dr. Ranajit Biswas from School of Women's Studies, Jadavpur University \&Swami Durganandaji Maharaj, Registrar of Ramkrishna Mission Vivekananda University, Belurmath. Another respondent organised awareness programme through state level seminar "NIVEDITA IN SEARCH OF THE LESSONKNOWN NIVEDITA: EK ONYO ONUSANDHAN 5th April 2018.Three respondents are in under process. 
The Data Number 9: Number of Employees in Workplace

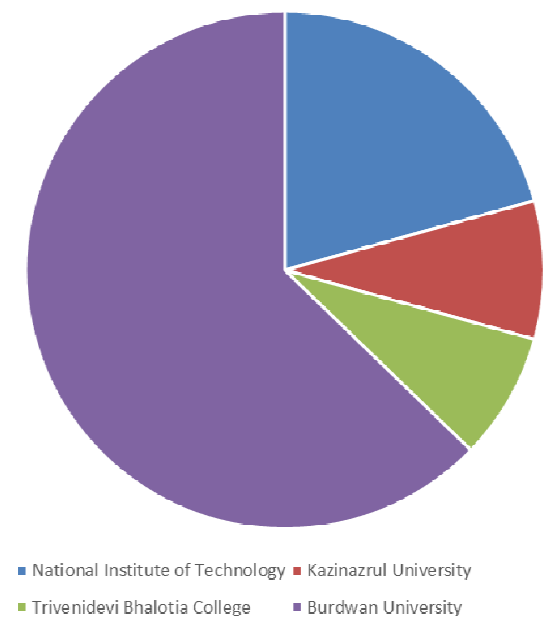

The above pie chart shows that several employees work in educational institutions for instance.

The Data No. 10: Providing Facilities to the ICC for dealing with complaints, conducting anenquiry into complaint of Sexual Harassment.

\begin{tabular}{|c|c|c|}
\hline $\begin{array}{c}\text { Facilities according to } \\
\text { the provision of SHW } \\
\text { Act }\end{array}$ & No. Respondents & Percentage \\
\hline Yes & 5 & 6.02 \\
\hline No & 78 & 93.97 \\
\hline Total & $\mathbf{8 3}$ & $\mathbf{1 0 0}$ \\
\hline
\end{tabular}

This table shows five respondents provide necessary infrastructure, official facility to the ICC such as CC camera and sufficient security personal for protection of women, from sexual harassment in educational institutions.

The Data No. 11: Process of securing the attendance of both the accused involved in sexually harassing women and the witness of sexually harassed women at the workplace before the ICC or LCC.

\begin{tabular}{|c|c|c|}
\hline Attendance of Accused & No. Respondents & Percentage \\
\hline $\begin{array}{c}\text { Yes, as per provision of the } \\
\text { rule }\end{array}$ & 5 & 6.02 \\
\hline N.A & 17 & 20.48 \\
\hline No & 61 & 73.49 \\
\hline
\end{tabular}

The above table shows that seventeen respondents replied no such incidence occurs, that is N.A. Five respondents replied yes, necessary support and assistance will be provided. Sixty one respondents are silent about this matter.

The Data No. 12: An official complaint of sexual harassment rendered to the LCC/ICC

\begin{tabular}{|c|c|c|}
\hline Official complaint & No. Respondents & percentage \\
\hline Yes & 5 & 6.02 \\
\hline No & 61 & 73.49 \\
\hline NA & 17 & 20.48 \\
\hline
\end{tabular}

The above table shows that only $6.02 \%$ respondents concern this matter. 
The Data No. 13: Employer's lodging an FIR or a Complaint before a competent court against outsiders sexually harassing his/her women employee in the vicinity.

\begin{tabular}{|c|c|c|}
\hline FIR provision & No. Respondents & Percentage \\
\hline Yes, as per provision of the rules & 5 & 6.02 \\
\hline Silent & 78 & 93.97 \\
\hline
\end{tabular}

The above table shows that only $6.02 \%$ assures the assistance to women, who are sexually harassed at the workplace for the lodging an FIR, before a police station or a Court under IPC and other laws. Other remaining respondents maintain silence about these issues.

The Data No. 14: Sexual harassment at workplace committed by the employee treat as misconduct included in the Service Rules by Employers.

\begin{tabular}{|c|c|c|}
\hline $\begin{array}{c}\text { Sexual harassment treat as } \\
\text { Misconduct under service rules }\end{array}$ & $\begin{array}{c}\text { No. } \\
\text { Respondents }\end{array}$ & Percentage \\
\hline Yes & 5 & 6.02 \\
\hline No & 78 & 93.97 \\
\hline
\end{tabular}

This table shows that five respondents are serious to tackle these issues.

The Data No. 15: Submission of Report by Employers regarding a several cases of sexual harassment and disposal by the ICC as well as District Officer. Report for the year 2013-2019

\begin{tabular}{|l|c|c|}
\hline $\begin{array}{c}\text { Disposal of cases by ICC as well } \\
\text { as District officer }\end{array}$ & No. Respondents & Percentage \\
\hline Yes & 5 & 6.02 \\
\hline No & 61 & 73.49 \\
\hline NA & 17 & 20.48 \\
\hline
\end{tabular}

This table shows that only 6.02 percentagesof employers submit the report of the cases of sexual harassment for the total period of 2013-2017.73.49\%respondents do not have any provision of above these issues. $20.48 \%$ do not make any provision above these issues.

The Data No.16: No suppression and no try to suppress the incident of Sexual Harassment.

\begin{tabular}{|c|c|c|}
\hline $\begin{array}{c}\text { Suppression of Sexual } \\
\text { Harassment of Women }\end{array}$ & $\begin{array}{c}\text { No. } \\
\text { Respondents }\end{array}$ & Percentage \\
\hline Yes & o & 0 \\
\hline No & 83 & 100 \\
\hline NA & 0 & 0 \\
\hline Total & $\mathbf{8 3}$ & $\mathbf{1 0 0}$ \\
\hline
\end{tabular}

This table shows that no one respondent tries to suppress.

NGO- Initiatives for Inclusion Foundation filed a PIL seeking SC's direction for enforcement of avarious provision of the Act. The petition stated that, it is submitted that though the law was enacted in 2013, the states /UTs are reluctant in implementing the law even after four years of enactment of laws, resulting in thebreach of fundamental rights of women and their dignity. ${ }^{17}$ Initiatives for Inclusion Foundation alleged in a PIL that most states and Union territories have failed to implement the law. ${ }^{18}$

\footnotetext{
${ }^{17}$ Amit Anand Choudhary @timesgroup .com, “Explain harass law lapses, SC tells centre and States” Times of India , January 12018

18 "Sexual abuse at work :SC notice to governments" Times of India, January 62018
} 


\section{CONCLUSIONS}

Sexual harassment at workplace is the crime against body; it breaks the mind and deteriorates not only the women's reputation, but also the workplace of the employer as well. Our civil society is culturally grounded and has always sanctioned the human violations and the burning examples are the oppression against women. We are in the twenty first century and globalized era, but still we try to humiliate women and do not even consider them as rational beings having the capability to manage things outside the domestic boundaries.Sexual harassment and silent sexual harasser provoke the women towards the feminization of poverty .SHW Act, 2013is an Act like "A thirsty crow find a small water drop in a big Jug". This offence is one kind of socio - economic disability and school children, students in colleges and universities, working women are very much affected thus becoming regular and prone victims. WCD minister Maneka Ghandhi tweeted that sexual harassment at workplace is a violent crime. She called upon the women to report the offence to thesexual harassment portal of the ministry. Complaints are to be filled anonymously at e-Box http://ncpcr.gov.in/index2.php or by mailing at min-wcd@nic.in. ${ }^{19}$ Kofi Annan, Secretary General of UN stated that "Gender equality is more than a goal itself." Therefore, everyone should promote gender equality and even empower women, which were one of the goals of The UN Millennium Development Goals (MDG) by the Year of 2015.My research study has shown that only a few employers in educational institutions have established the Internal Complaint committee to combat sexual harassment at workplace. Now, Sustainable Development Goal 5 is framed to achieve gender equality and empower all women and girls. Thus, due to the transfer of the job of the employee in District level, the Local Complaint Committee is not stable. State Government should launch one drive programme to identify the default in educational institutions and impose a heavy penalty upon them. Awareness programme should be introduced through media about these issues, including mass awareness camps, legal awareness camp and nukkadnataks to combat such.

\section{REFERENCES}

1. Vishaka V. State of Rajasthan AIR 1997 SC3011

2. Walker V. Northumberland County Council (1995) 1 ALLER737

3. Railway Board V. Chandrima Das (2000) 2 SCC 988

4. Jay Laxmi Salt Works (p) Ltd. V. State of Gujrat(1994) 3 SCC492

5. MedhaKotwalLele V. Union of India WP(Crl)No 173- 177 of 199

6. Convention on Elimination of All Forms of Discrimination Against Women( CEDAW) 1979

7. The Nairobi Looking Strategies for the Advancement of Women, 15-26 July 1985

8. The Vienna Declaration and Programme of Action in 1993

9. Declaration on the Elimination of Violence Against Women, 1993

10. Beijing Declaration and Platform for Action 1995

11. The Elimination of Violence and Harassment Convention, 2019 ( No. 190) and Recommendation (No. 206)

12. Constitution of India, 1950

13. Indian Penal Code, 1860

${ }^{19}$ Times News Network, “Minister: Use WCD portal to report sexual harassment” Times of India, October 102018 
14. Criminal Law Amendment Act,2013

15. Evidence Act, 1872

16. Information Technology (Amendment) Act,2008

17. Indecent Representation of Women (Prohibition) Act, 1986

18. The National Commission for Women Act, 1990

19. The Sexual Harassment of Women (Prevention, Prohibition and Redressal) Act, 2013

20. Catherine Alice Mackinnon ( 19979) 'Sexual Harassment of Working Women : A Case of Sex Discrimination, edl 19 ${ }^{\text {th }}$, Yale University Press, New Haven and London

21. Mamta Rao Law relating to 'Women \& Children,edl $2^{\text {nd }}$, Eastern Book Company, Lucknow

22. Shoma A Chatterjee, 'Women in perspective: essay on your gender issues,edl, Vitasta Pub. House, New Delhi

23. Dr.Jayanta Mete \&PrathitaBiswas, Gender School and Society 'edl $2^{\text {nd }}$, Rita Book Agency, Kolkata

24. ThapanMeenakshi( 2009) 'Living The Body Embodiment, ' Womanhood and Identity in Contemporary India ,'edl $1^{\text {st }}$, Sage Publication, New Delhi and India,

25. HarapriyaMahapatra, "Status of Women in India Society" Volume - 3, Issue - 6, Journal of Research in Humanities and Social Science, p33- 36(2015)

26. Indrani Mazumdar \& Neetha N, "Gender Dimension Employment Trends in India, 1993 -94 to 2009 -10" Vol 46, Issue No.43, Economic \% Political Review p118 - 126(2011)

27. The All India Survey on Higher Education 2014 -15, Ministry of Human Resource Development, Department of higher Education, New Delhi

28. Know Your Rights Sexual Harassment of Women at the Workplace published by National Human Rights Commission , New Delhi

29. Times of India

30. Nasir, M., \&Shaukat, A. (2013). A Study to Investigate the Physical And Psychological Effects of Sexual Harassment on Working Women in KallaurKot. International Journal of Educational Science and Research (Ijesr), 3(3), 21-34.

31. Masthanaiah, T., \& Reddy, K. R. Perceived Sexual Risk Baheviour of Hiv/Aids Among Men Migrant Workers in Mumbai.

32. Kumar, A., Nigam, S., Sharma, R., \&Martoliya, D. A Study on Prevalence of Reproductive Tract Infection Sexually Transmitted Infections and its Determinants in Adult Population of Kanpur Nagar. 